\title{
The Northwest Passage in the Arctic: A Brief Assessment of the Relevant Marine Transportation System and Current Availability of Search and Rescue Services
}

\author{
Rebecca Sheehan ${ }^{1, *(\mathbb{D})}$, Dimitrios Dalaklis ${ }^{2}{ }^{(}$, Anastasia Christodoulou ${ }^{2}\left({ }^{\circ}\right.$, Megan Drewniak $^{3}$, Peter Raneri ${ }^{4}$ \\ and Angelos Dalaklis ${ }^{5}$ \\ 1 U.S. Coast Guard on Secondment, Maritime Safety and Environmental Administration, \\ World Maritime University, 21118 Malmö, Sweden \\ 2 Maritime Safety and Environmental Administration, World Maritime University, 211 18, Malmö, Sweden; \\ dd@wmu.se (D.D.); ac@wmu.se (A.C.) \\ 3 U.S. Coast Guard, Marine Safety Unit Toledo, Toledo, OH 43604, USA; megan.l.drewniak@uscg.mil \\ 4 U.S. Coast Guard, Marine Safety Unit Baton Rouge, Baton Rouge, LA 70809, USA; peter.j.raneri@uscg.mil \\ 5 Henley Business School, University of Reading, Reading RG6 6UD, UK; a.dalaklis@student.reading.ac.uk \\ * Correspondence: rs@wmu.se
}

\section{check for}

updates

Citation: Sheehan, R.; Dalaklis, D.; Christodoulou, A.; Drewniak, M.;

Raneri, P.; Dalaklis, A. The Northwest

Passage in the Arctic: A Brief

Assessment of the Relevant Marine Transportation System and Current Availability of Search and Rescue

Services. Logistics 2021, 5, 23.

https://doi.org/10.3390/

logistics5020023

Academic Editor: Robert Handfield

Received: 1 March 2021

Accepted: 18 March 2021

Published: 19 April 2021

Publisher's Note: MDPI stays neutral with regard to jurisdictional claims in published maps and institutional affiliations.

Copyright: (c) 2021 by the authors. Licensee MDPI, Basel, Switzerland. This article is an open access article distributed under the terms and conditions of the Creative Commons Attribution (CC BY) license (https:// creativecommons.org/licenses/by/ $4.0 /)$.
Abstract: The analysis in hand provides a brief assessment of the United States' and Canada's marine transportation system and relevant search and rescue (SAR) support in relation to the Northwest Passage, with the purpose of examining to what extent these countries' relevant infrastructure resources are able to meet the expected growth of shipping operations and business activities in the Arctic. Through an extensive literature review, this assessment will specifically describe the most important influences upon the maritime transportation system, with the issue of certain geographical details and the capabilities of existing ports standing out. Additionally, vessel activity trends and vessel traffic routing measure initiatives will be examined. Furthermore, the SAR infrastructure details and means to render assistance to people in distress along the Northwest Passage will be discussed. The reality remains that port characteristics are limited and vessel traffic routing measure initiatives and upgrades to SAR assets are commendable but slow-paced. It is true that both the United States and Canada are taking proper measures to build up infrastructure needs, but they both may run out of time to put adequate infrastructure in place to deal effectively with the changing environment.

Keywords: Arctic shipping; infrastructure; marine transportation system; search and rescue (SAR); logistics

\section{Introduction}

Harsh environmental conditions and remoteness characterize the wider Arctic region, which is a rather difficult and dangerous area to live and conduct business endeavors within. The marine transportation system and search and rescue (SAR) support are two critical components of infrastructure needed to prevent harm potentially arising from ship operations and business activities along the Arctic's Northwest Passage. A resilient transportation system is a vital component of a region's infrastructure, especially for remote and isolated communities in the Arctic. As a subset of a nation's overall transportation system, a robust marine transportation system facilitates effective and efficient movement of vital supplies, raw materials and energy resources, as well as final products, through ports and waterways. Ports are critical transportation links, especially when communities lack other connections, such as in the case of the Arctic. Furthermore, initiatives to develop voluntary traffic separation schemes support navigable waterways and are a vital part of the marine transportation system. It is also necessary to highlight the fact that because of the harsh conditions of the dynamic Arctic region, which is characterized by numerous 
record-setting events, as well as vast distances involved and remoteness, SAR support capabilities hold a very important role: to ensure safe and secure vessel operations in the region under discussion. It is not a coincidence that the year 2020 revealed record warm surface air temperatures in the Eurasian Arctic, record low sea ice extent in the Laptev Sea, record low snow cover across the Eurasian Arctic, significant ice loss in the Greenland Ice Sheet, and a sharp decline in tundra greenness in North America [1].

During the last two decades, the ability to observe how the Arctic is changing has made notable progress and the world is clearly taking notice. Shipping activities in the Arctic have clearly increased and there is an obvious reason behind this: sea ice coverage has diminished from 6.1 million square kilometers in 1999 to 4.3 million square kilometers in 2019 [2]. Additionally, the length of the navigation season has been growing by as much as 7 to 10 days each year and may extend by 2.5 months over the next decade [3]. These changing conditions have resulted in increased attention from government, media, scientific researchers, the natural resource exploration industry, and even entities engaged in touristic activities and relevant business opportunities. The message is clear: the Arctic is indeed undergoing a formative transformation. Initiatives such as the Arctic Observing Network (AON) systems, completion of the Multidisciplinary Drifting Observatory for the Study of Arctic Climate (MOSAiC) project, and opening of the new National Oceanic and Atmospheric Administration (NOAA) Barrow Observatory have increased the capacity and ability to predict Arctic climate and environmental change, including sea ice predictions, affecting the oceans [1].

The continuous melting of ice is transforming the Arctic region into the most rapidly warming region of the planet, most commonly identified with the North Pole and quite synonymous with the term "Arctic Circle" [4]. Before proceeding any further, it is necessary to specify the Arctic boundary considered for the purposes of this analysis. For both the United States and Canada, the "Arctic" is defined as the area containing the Arctic Ocean as well as the respective territories with a latitude higher than the Arctic Circle (66 $33^{\prime} 48^{\prime \prime}$ $\mathrm{N})$. Area within the Arctic Circle includes lands divided among eight countries: United States (Alaska), Canada, Denmark (Greenland), Iceland, Norway, Sweden, Finland, and Russia. The United States and Canada are among five of these eight countries that have an Arctic coastline. Their geographic positions being located adjacent to emerging shipping corridors creates important obligations in terms of navigation safety and responsibility to render search and rescue assistance [5].

The main objective of this analysis is to present the infrastructure needs of the Arctic with a focus on the maritime transportation system and SAR services along the Northwest Passage. The supply chain resiliency and availability of physical infrastructure adjacent to navigable waters should be an area of concern, especially by factoring in the expected growth of the number of ships that will be operating in the region under discussion. Therefore, the analysis provides an overview of the Northwest Passage along with an examination of viable transportation links. Given the transformative environmental conditions and anticipation of increased vessel traffic, an integral part of the analysis is to highlight the current state of vessel activity trends, along with vessel traffic routing measure initiatives. Furthermore, it is vital to highlight the significant resource gaps related to emergency management coordination with an examination of SAR support capabilities.

First, to achieve this goal, an extensive literature review was carried out. The relevant maritime transportation system and SAR infrastructure capabilities were identified as a result of this activity. The methodology adopted included research techniques and analysis of documents and materials from governmental scientific agencies, high-level intergovernmental forums, integrated governmental action teams, federal interagency coordinating committees, scientific peer-reviewed articles, governmental press release statements, government proposed rules and public notices, International Maritime Organization (IMO) publications, and community-specific infrastructure profiles. In view of anticipated issues with future developments within this region, this approach will consider the pursuit of vessel traffic management initiatives and the process related to international approval and 
recognition of such initiatives. This also raises the issues of how the current state of marine transportation system and SAR infrastructure will fare against the vessel activity trends and growing environmental risks and concerns. The increasing trend of vessel activity and environmental concerns in the Arctic has challenged decision-makers to carry out immense infrastructure improvements and studies. Predicated on the previous issues, a question has been raised about the adequacy of infrastructure in the Arctic. This paper has identified, analyzed, and evaluated the impact of operations and infrastructures from the maritime logistics perspective. The results obtained from this paper will assist both the United States and Canada to develop their substantial strategies for adapting to the new paradigm of increased future vessel activity in the Arctic.

This assessment consists of four main sections. The first one provides a description of the Northwest Passage, including the existence or not of viable transportation links. The second section explores the current state of vessel activity trends along this route. The third section examines vessel traffic routing measure initiatives. The fourth and final section investigates the existing SAR capabilities and provides a few necessary recommendations to ensure that the future expected traffic increase in this region will also be associated with better support towards crossing maritime traffic.

\section{The Northwest Passage and Viable Transportation Links}

\subsection{The Northwest Passage}

Maritime activities in the Arctic region give emphasis to four main shipping routes, which include the Arctic Bridge, Northern Sea Route, Northwest Passage, and (even put forward the possibility to take advantage of a) Transpolar Sea Route [4]. An alternative to the Panama Canal, the Arctic's Northwest Passage links the Atlantic and Pacific Oceans through the Canadian Arctic Archipelago from Baffin Bay to the Bering Strait. The shipping distance of the Northwest Passage is substantially less than the traditional route of the Panama Canal. The transit between East Asia and Western Europe would take approximately 13,600 km using the Northwest Passage, compared to 24,000 km using the Panama Canal [6]. Essentially, these voyages take around half the time and benefit by saving money on fuel and reducing the amount of emissions produced [7]. The Northwest Passage encompasses several route options with different variations with common eastern and western approaches. While the distance may be less when compared to the Panama Canal, the geography along this passage complicates navigation. Drifting ice often makes these routes difficult for large vessels and leaves only narrow or shallow shipping corridors open [5].

The United States and Canada have a positive history of strong collaboration in the Arctic despite an ongoing disagreement in relation to effective Arctic governance and the legal status of the Northwest Passage [8]. More specifically, the dispute centers upon the status and legal regime of the various water corridors that make up the different routes. Canada maintains the view that these waters are internal waters, which fall under Canada's authority and jurisdiction. The United States maintains the position that the Northwest Passage is an international strait, an area of high seas status. The 1988 Canada-United States Agreement on Arctic Cooperation (ACA) signaled that both sides agree to disagree in order to work together and proceed with resolving issues of mutual interest and concern [9]. Thus, the status quo has since proven fruitful: the United States and Canada have both embraced a shared Arctic leadership model with a foundation that emphasizes cooperation. The two countries strive to embrace opportunities and confront challenges with the following objectives: conserving Arctic biodiversity through science-based decision-making, incorporating Indigenous science and traditional knowledge into decision-making, building a sustainable Arctic economy, and supporting strong Arctic communities [10]. This shared mindset and eagerness for collaboration is vital to realistically recognize and address infrastructure needs relating to the maritime transportation system and SAR support along the Northwest Passage. 


\subsection{Viable Transportation Links}

One challenge that both the United States and Canada face is the reality of limited viable transportation links along the Northwest Passage. Essentially, no fixed links exist between communities, which are largely isolated from one another. Inland roads and railway projects do not yet play a substantial role in supplying Arctic communities with essential goods and services. Airports are a mainstay in the Arctic region for both countries, but community resupply of fuel and cargo over water is much more economically feasible as barge deliveries are traditionally less expensive than moving cargo by air. Coastal ports exist, but with minimal capabilities and significant environmental risks/concerns. The data on the different coastal ports were collected from a range of sources and the relevant information is summarized in Figure 1, with additional details being also provided via two respective tables that can found in Appendix A.

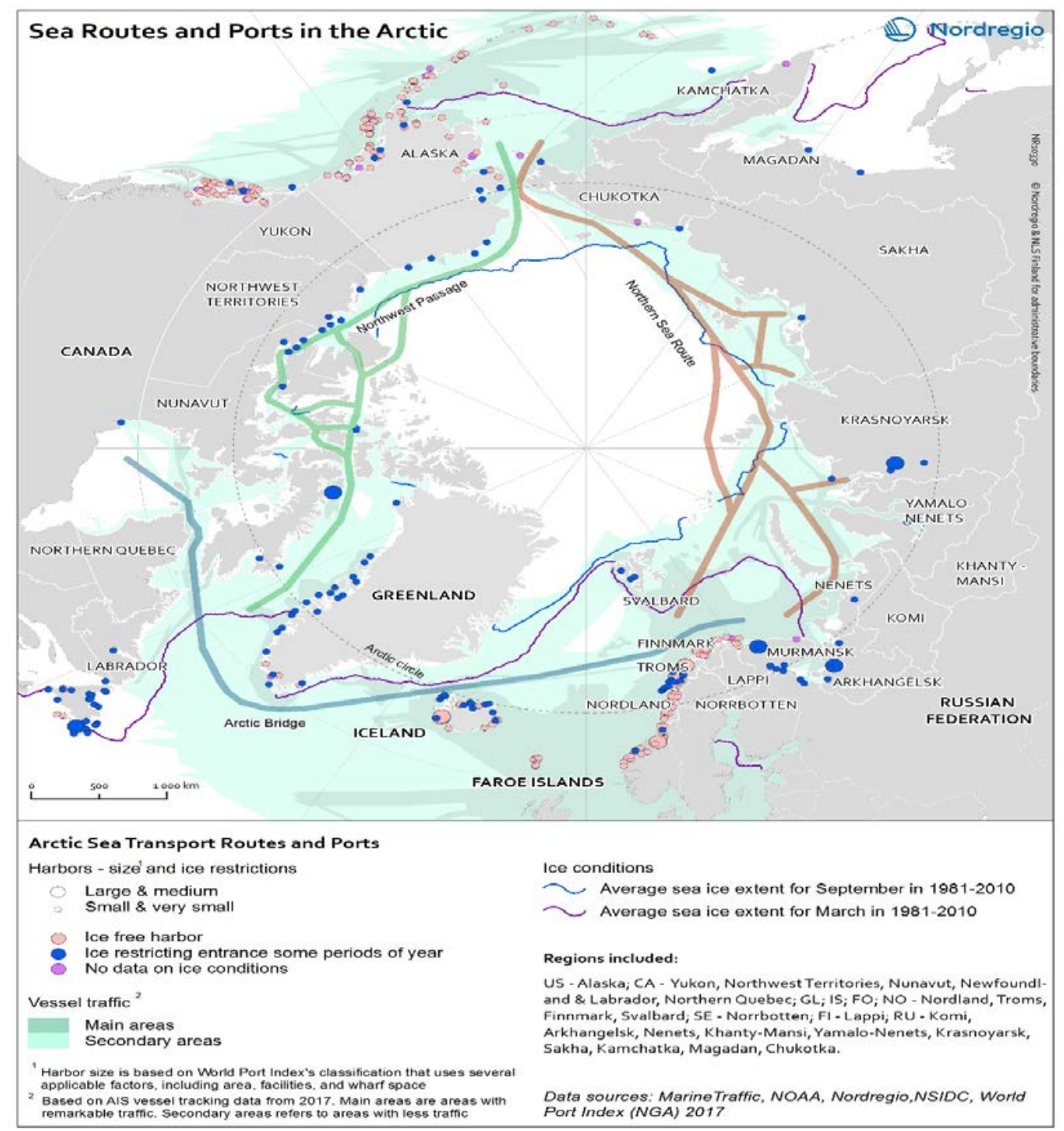

Figure 1. Sea routes and ports in the Arctic. Designer/Cartographer: Eeva Turunen. Courtesy of Nordregio [11].

In the Arctic region of the United States, several coastal port communities contribute to the maritime transportation system. However, shipping operations primarily rely on barges and beach landings. Airplane service bolsters the port communities' viability as transportation links, but there are essentially no inland roads connecting these coastal ports, with the exception of Prudhoe Bay and Red Dog. Prudhoe Bay is accessible via the 
James W. Dalton Highway (Alaska Route 11), which is mostly gravel and extremely remote. No inland roads provide a transportation link to Red Dog, except for one that links the Port to the Red Dog Mine.

The situation is the same in Arctic Canada. Coastal ports exist, but with limited capabilities and significant environmental risks/concerns. Airplane services bolster Arctic Canada's transportation capabilities and few inland roads exist. Since air service is so expensive, $95 \%$ of goods in the Canadian north are shipped by sea [12]. In Canada's Northwest Territory region, marine transportation services successfully overcame challenges of record high water levels and COVID-19 restrictions to complete their 2020 marine resupply season. The shipping operation took place between 10 July 2020 and 19 September 2020, with a delivery of 27.9 million liters of fuel and 2720 tons of cargo to port communities within the Northwest Territories [13].

It is expected that shipping operations in the region under discussion will continue to increase in the future, especially as expansion project proposals come to fruition. There is a range of size and scope of awarded marine infrastructure projects with varying impact. In Pond Inlet, construction work involves a small craft harbor and wharf for large vessel access [14]. Other projects are more ambitious, such as the initiative from Baffinland Iron Mines Corporation. The company hopes to expand operations for the Mary River Project by building a 110-km rail line from Mary River Mine to Milne Inlet Port, adding a second ore dock at the port to increase production from $6 \mathrm{Mt}$ to $12 \mathrm{Mt}$ of iron ore per year [15,16]. This initiative comes with legitimate concerns, however, such as the potential for shipping to interfere with local hunting, for vessels to affect marine mammals, and for shipping to harm the health of the marine ecosystem [17].

\section{Vessel Activity Trends}

The marine shipping corridor of Arctic Canada's Northwest Passage has experienced significant growth in maritime traffic in recent years. The volume of traffic almost tripled between 1990 and 2015 [18]. Looking further past the year 2015, the total number of trips within the Northwest Passage increased from 443 in 2015 to 760 in 2017 [19]. Considering the option to utilize the Northwest Passage as a continuous route between the Pacific and Atlantic Oceans, a total of 313 complete transits of the Northwest Passage had been made by the end of the 2019 navigation season [20]. Vessel activity trends indicate an increase in resupply shipments, activities in support of mining, oil, and gas exploration, and even touristic activities [21]. In particular, the later should be a point of concern, in case a mass rescue operation will take place in the remote Arctic environment. In any case, these zones of various marine activities along the Northwest Passage are summarized in Figure 2. 


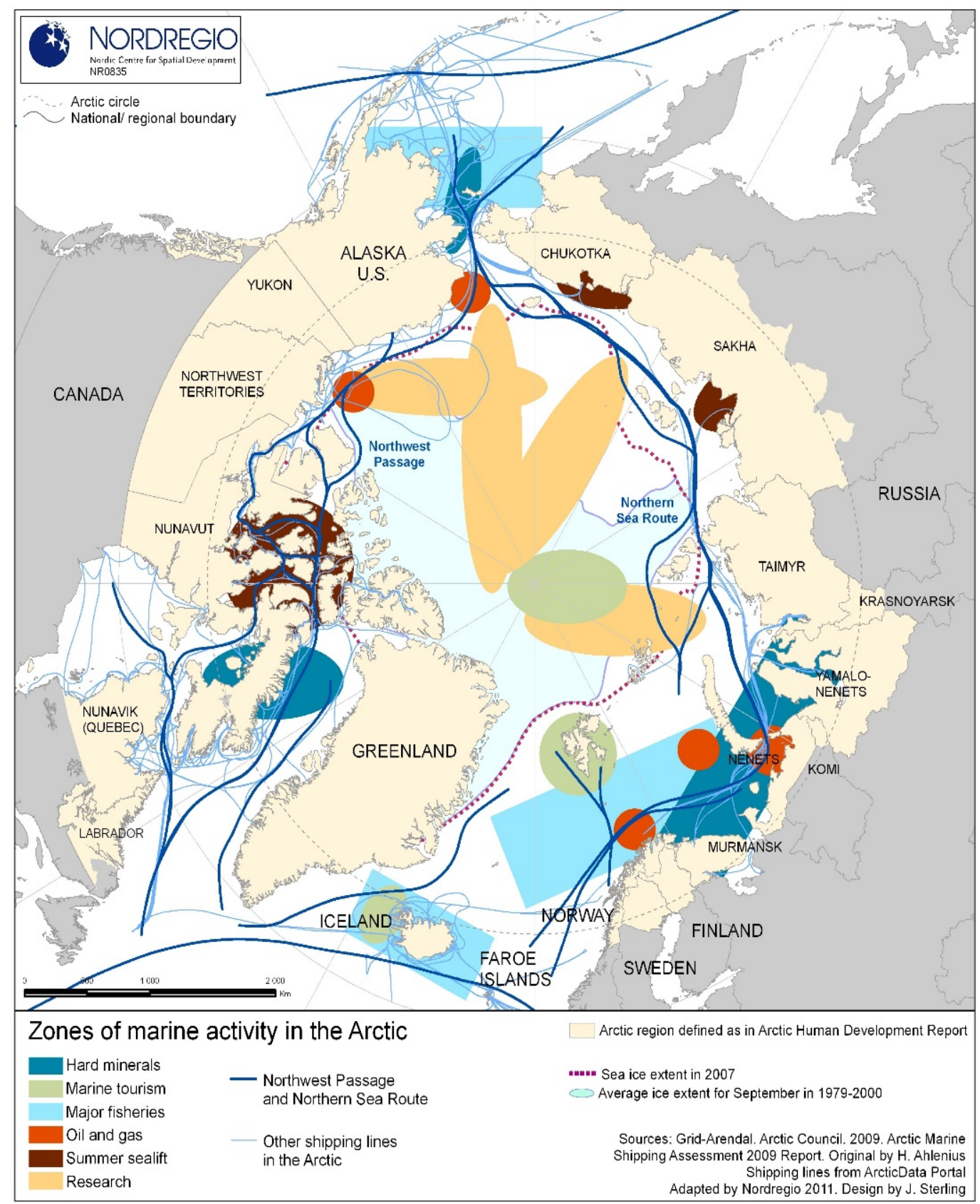

Figure 2. Zones of marine activity in the Arctic. Designer/Cartographer: original by H. Ahlenius, adapted by Jose Sterling. Courtesy of Nordregio [22].

Overall, shipping in the Arctic has increased by 25\%, from 1298 ships in 2013 to 1628 ships in 2019 [2]. Vessel traffic is still low, but steadily increasing. There is significant interest in shipping of hard minerals and thus the distance sailed by bulk carriers in the Arctic Polar Code area has risen by 160\% between 2013 and 2019 [2]. Contributing to this extensive increase at the eastern end of the Northwest Passage, the Canadian Mary River Mine opened in 2014. The subsequent influence on traffic has noticeably increased bulk carrier transits along the Northwest Passage as observed from 2013 to 2019 (Figure 3). 


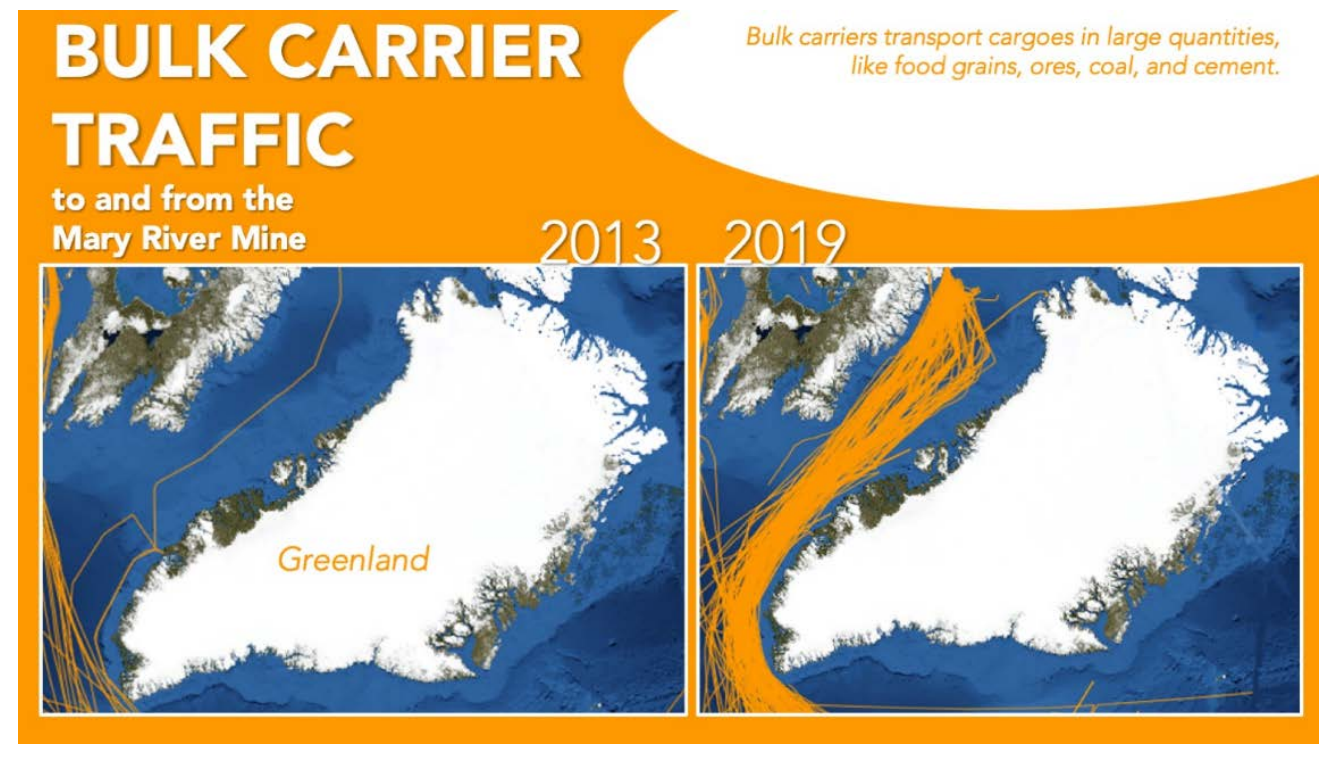

Figure 3. Bulk carrier traffic to and from the Mary River Mine. Courtesy of PAME-Arctic Shipping Status Report, available online: https:/ / pame.is / projects/arctic-marine-shipping/arctic-shipping-status-reports/723-arctic-shipping-report-1the-increase-in-arctic-shipping-2013--2019-pdf-version/ file (accessed on 18 March 2021) [2].

There is significant economic value in regard to shipping operations and business activity in the United States' Arctic region. Within the 1,000,000 square miles of U.S. Territorial Waters and Exclusive Economic Zone, highlights include Alaska's USD 3 billion Arctic seafood industry, a USD 1 trillion value of rare earth minerals, 90 billion barrels of undiscovered oil reserves, and an estimated 30 percent of the world's undiscovered natural gas [23]. Reductions in permanent sea ice have exposed coastal boarders and longer seasons of reduced ice conditions have facilitated increased economic activity interest to include commercial transportation and resource development. This increased activity demands the use of innovative maritime transportation system tools and SAR support to understand and manage the evolving risk.

In cooperation with the U.S. Coast Guard and U.S. Arctic Research Commission, the Coastal Response Research Center of the University of New Hampshire hosted a workshop in 2008 that was focused on the risk factors for plausible Arctic marine incidents. Along the Northwest Passage, these potential incidents included a cruise ship grounding, a bulk carrier trapped in ice, fire and collision in offshore operations, and a tug losing power and subsequently grounding while towing a barge laden with explosives [24]. More than a dozen years have passed since that workshop, but the risks associated with such incidents are even more plausible now than before. As more ships operate in the Arctic, the need for support is inevitable and should be provided in a timely manner.

A very extended number of drivers may help to predict overall vessel activity along the Northwest Passage. In 2018, the U.S. Arctic Research Commission and the Woodrow Wilson Polar Institute supported the U.S. Committee on the Martine Transportation System with a technical workshop, which brought together 41 experts from industry, academia, government, and the Arctic region. Over 70 various drivers were identified and ranked in categories to include natural resources, the global economy, changing geopolitics, regulatory changes, infrastructure, improved technology and operations, environmental change, the human element, and a changing fuel landscape. Ultimately, the research scenario results suggest that the number of ships in Northern U.S. Arctic waters and the surrounding region will increase by 136-346\% over 2008 levels [3]. These results provide an update to the 2015 report by The International Council on Clean Transportation (ICCT), commissioned by the U.S. Committee on the Marine Transportation System to support the priorities outlined in the U.S. National Strategy for the Arctic Region [25]. 
Finally, it is important to note that the vast majority of maritime activities in this region is associated with small-sized crafts. Unfortunately, they are the most difficult type to deal with in regard to SAR operations, because of their limited associated equipment/communications capabilities [21]. Diminishing sea ice conditions may increase the opportunities for shipping and business activities, but ice still represents a risk; remoteness and unpredictable environmental weather conditions should also be factored in.

\section{Vessel Traffic Routing Measure Initiatives}

\subsection{Role and Function of the IMO}

Vessel traffic management is an important component of the marine transportation system. Increased predictability of established vessel traffic patterns enhances safety by decreasing the potential for collisions (and at the same time can prevent the associated environmental damage caused by oil spills, which is the most common result of an accident) since mariners may be better able to predict where vessel interactions may occur and act accordingly [26]. Vessel Traffic Separation Schemes and Precautionary Areas are generally accepted by the maritime community as positive vessel traffic management tools that reduce risk. The key to making a safety impact is to conduct a thorough marine casualty analysis as part of the development and planning process. The International Maritime Organization (IMO) fulfills an important role and function in regard to vessel traffic routing measure initiatives as the recognized international authority. Established in 1948, the IMO is a specialized United Nations agency with the mission "to promote safe, secure, environmentally sound, efficient, and sustainable shipping through cooperation" [27]. The IMO's involvement is essential for ensuring internationally coherent solutions to waterway infrastructure needs relating to the maritime transportation system. The process in approaching the IMO to secure the adoption of vessel traffic routing measures requires a Member State of the IMO to develop and submit a formal proposal to justify the need for the proposed action [28]. Member States submit proposals to the IMO's Sub-Committee on Navigation, Communications and Search and Rescue (NCSR). This sub-committee then evaluates the proposal and makes a recommendation regarding its adoption. Lastly, the recommendation continues to the Maritime Safety Committee (MSC) for adoption [29]. Approved by the MSC at its 101st session, the most current procedure responds to noted concerns of the NCSR regarding conformity of previously submitted proposals [30]. In the United States, responsibility to submit these proposals to the IMO lies with the U.S. Coast Guard and proposals originating from Canada are submitted by Transport Canada [28]. Both countries benefit from their vessel traffic routing measure initiatives, both past and present. Ongoing efforts will eventually require IMO's input and approval as they strive to upgrade the marine transportation system infrastructure in the form of Port Access Route Studies and Low Impact Shipping Corridor Initiatives.

\subsection{Port Access Route Studies-United States}

In accordance with United States' rulemaking procedures, the Ports and Waterways Safety Act requires the U.S. Coast Guard to conduct a Port Access Route Study (PARS) before establishing new or adjusting existing fairways or traffic separation schemes. The intent is to reconcile the need for safe access routes with other reasonable waterway uses. As the lead federal agency within the United States for vessel traffic routing measure initiatives, the U.S. Coast Guard is responsible for coordinating with Federal, State, and foreign state agencies (if applicable) and must consider the views of maritime community representatives, environmental groups, and other interested stakeholders. If the PARS recommends vessel routing measures, the U.S. Coast Guard initiates the domestic rulemaking process and/or the International Maritime Organization (IMO) ships' routing measures process. Objectives of the PARS are to:

1. Determine present traffic density;

2. Determine potential traffic density;

3. Determine if existing vessel routing measures are adequate; 
4. Determine if existing vessel routing measures require modifications;

5. Determine the type of modifications;

6. Define and justify the needs for new vessel routing measures;

7. Determine the type of new vessel routine measures; and

8. Determine if the usage of the vessel routing measures must be mandatory for specific classes of vessels [31].

The first internationally recognized measure for navigation in polar waters approved by the IMO was the proposal jointly submitted by the United States and Russia. Developed in response to increased activity in the region, the United States and Russia proposed voluntary routing measures in the Bering Strait and Bearing Sea to the IMO [32]. The IMO approval established six recommendatory two-way routing measures and six precautionary areas. Voluntary use of these shipping lanes is the first step towards a more comprehensive traffic management route system [33]. Prior to submitting jointly with Russia to the IMO, the United States had completed a successful Bering Strait PARS in accordance with national guidelines. The Bering Strait PARS now serves as a useful template for similar traffic management initiatives further along the Northwest Passage.

In response to the changing sea conditions affecting the Northwest Passage and in anticipation of a potential increase in vessel traffic, the U.S. Coast Guard is now working in close coordination with Canada for the North Slope Alaskan Arctic Coast PARS, aimed at improving shipping safety in Chukchi and Beaufort seas. Public comment opened on 21 December 2018 and has been extended to 30 September 2021. The objectives are to analyze current vessel patterns, predict future vessel needs, and balance the needs of all waterway users by developing and recommending vessel routing measures for the Arctic [34]. At this stage in the PARS, the U.S. Coast Guard is particularly interested in identifying specific locations, times, or instances where future vessel activity could increase significantly in density or cause specific undesirable consequences [35].

\subsection{Low Impact Shipping Corridor Initiative-Canada}

In regard to developing traffic management measures in the Arctic, Canada's equivalent of the United States PARS is essentially the Low Impact Shipping Corridors Initiative. Otherwise earlier referred to as the Northern Marine Transportation Corridors Initiative, the development depends on interagency coordination and involves three key federal government departments to include the Canadian Coast Guard, the Canadian Hydrographic Service, and Transport Canada [36]. Objectives of this government initiative in partnership with the Arctic Corridors Research Project included the following: develop a long-term geospatial ship track database in Arctic Canada, identify temporal and spatial shipping trends, establish zones of high commercial and non-commercial shipping activity, document culturally significant marine areas, and establish potential management strategies for the low impact shipping corridors [37]. The Low Impact Shipping Corridor Initiative uses a comprehensive strategy whereby infrastructure and services are systemically identified through a risk-based approach [38]. Commendable consideration and prioritization is given to the potential impact of local community cultural and livelihood activities. This initiative confirms that the responsible maritime entities are most definitely moving in the right direction, but it will still take significant time to implement the services and infrastructure necessary to provide a transportation system to the level of adequacy seen elsewhere in Canada [38].

\section{SAR Support Capabilities}

In 1996, the Arctic Council officially formed as a cooperative forum to address issues of sustainable development and environmental protection in the Arctic [39]. Since its establishment, actions taken by the Arctic Council to allocate SAR resources on an international level have streamlined new policies and bipartisan agreements to improve infrastructure needs in the region [40]. In May 2011, the Arctic Search and Rescue Agreement (formally known as the Agreement on Cooperation on Aeronautical and Maritime SAR in the Arctic) 
was signed, making it the first legally binding agreement negotiated under the auspices of the Arctic Council [41]. Signed by eight countries including the United States and Canada, this agreement coordinated international maritime and aeronautical SAR coverage and designated competent authorities, search and rescue agencies, and rescue coordination centers (Table 1).

Table 1. Summary table of SAR agreement. ${ }^{1}$

\begin{tabular}{|c|c|c|c|}
\hline Country & Competent Authority & SAR Agencies & Rescue Coordination Centers \\
\hline United States & U.S. Coast Guard & $\begin{array}{c}\text { U.S. Coast Guard; } \\
\text { U.S. Department of Defense }\end{array}$ & $\begin{array}{c}\text { Joint Rescue Coordination Center Juneau } \\
\text { (JRCC Juneau); } \\
\text { Aviation Rescue Coordination Center } \\
\text { Elmendorf (ARCC Elmendorf) }\end{array}$ \\
\hline Canada & $\begin{array}{l}\text { The Canadian Minister of } \\
\text { National Defence }\end{array}$ & $\begin{array}{c}\text { Canadian Forces; Canadian } \\
\text { Coast Guard }\end{array}$ & $\begin{array}{c}\text { Joint Rescue Coordination Centre, } \\
\text { Trenton }\end{array}$ \\
\hline
\end{tabular}

${ }^{1}$ Agreement on Cooperation on Aeronautical and Maritime Search and Rescue in the Arctic [42].

On 7 May 2019, the Arctic Council held its Eleventh Ministerial Meeting in Rovaniemi, Finland. Both the United States and Canada were at the meeting, which commended those exercises that have advanced the implementation of the SAR agreements and encouraged the continuation of exercise activities aiming at deepening practical cooperation with the Arctic Coast Guard Forum [43]. This statement was a continuation of the declaration made at the Arctic Council's Tenth Ministerial Meeting in Fairbanks, Alaska, which welcomed the operational exercises that have advanced the implementation of the SAR Agreement [44]. The benefits of SAR exercise activities include the development of lessons learned and best practices critical to improving upon current SAR support infrastructure and strategies.

While a lack of SAR assets still exists, the U.S. Coast Guard is unable to maintain year-round surface presence and mitigates the risk through partnerships and the forward deployment of assets during times of increased maritime activity [45]. Operation Arctic Shield is key to the strategy that acknowledges the infrastructure needs in regard to SAR support. An annual operation that began in 2009, Operation Arctic Shield is a year-round planning and operational endeavor that applies a risk-based approach and leverages tribal, community, and interagency partnerships to integrate U.S. Coast Guard surface, aviation, and shore-side resources to conduct a broad range of search and rescue activities [23]. In 2020, air assets included two MH-60 Jayhawk helicopters, a 225-foot seagoing buoy tender, and a 420-foot medium icebreaker [46]. Over the past several years, the United States has consistently staged two helicopters in Kotzebue and the number and type of on-the-water assets have not changed significantly. Until additional surface assets (icebreakers) are delivered, the United States will need to continue with its mobile, scalable, and seasonal approach to mitigating risk [45].

Canada takes a similar seasonal approach to executing its SAR mission in the Arctic, but with considerably more resources. SAR assets deployed in the Canadian Arctic for its 2020 season included a total of eight icebreakers. The Marine Communications and Traffic Services Centre in Iqaluit provided support to 128 vessels (cargo ships, research vessels, bulk carriers, fishing vessels, and Canadian Coast Guard ships) in the Northern Canada Vessel Traffic Services Zone (NORDREG). It is also important to note that the Inshore Rescue Boat station in Rankin Inlet, NU, bolstered local SAR response. Under the Oceans Protection Plan and through the Canadian Coast Guard Auxiliary's Indigenous Community Boat Volunteer Pilot Program, three local communities received search and rescue capable boats and equipment. Additionally, the Canadian Coast Guard's Training and Exercise Program participated in seven exercises with notable government and industry partners [47]. The 2020 season offers a typical snapshot of Canada's typical SAR support capability in the Arctic.

It is a rather self-explanatory fact that both the United States and Canada must build up and invest in more supporting SAR infrastructure to include surface, aviation, and 
communication assets along with shore-based infrastructure. The mobile, scalable, and seasonal approach works, but requires a solid foundation of basic logistics and support functions. To address their SAR infrastructure needs, the United States and Canada should continue to pursue the strategic goals of the Arctic Coast Guard Forum (ACGF). Established in 2015, the ACGF can help to enhance collaboration as vessel activity increases by acting as a platform to potentially pool of resources to establish SAR centers at geographically relevant locations in the Arctic [48].

\section{Conclusions}

This assessment critically summarized the environmental risks and concerns along the Northwest Passage, existence or not of viable transportation links, vessel activity trends, vessel traffic routing measure initiatives, and SAR support capabilities. The Arctic continues to garner significant international attention due to reduced sea ice cover and longer navigable shipping seasons. The maritime industry has not seen such transformative changes since the opening of the Suez and Panama Canals [5]. Vessel traffic is still relatively low, but steadily increasing with associated risk. The United States and Canada are among the group of Arctic nations that have a responsibility to provide infrastructure support vital to marine safety and environmental protection. The safe, secure, and environmentally sound transportation of people, goods, and materials by water is essential to all Arctic region stakeholders. A healthy maritime transportation system and robust SAR infrastructure is vital. The reality remains that the port characteristics of communities along the Northwest Passage are limited. Vessel traffic routing measure initiatives and upgrades to SAR assets are commendable but slow-paced. It is true that both the United States and Canada are taking proper measures to build up infrastructure needs, but they both may run out of time to put adequate infrastructure in place to deal effectively with the changing environment.

Author Contributions: Writing—original draft preparation, R.S.; writing—review and editing, D.D., A.C., M.D., P.R., and A.D.; visualization, D.D.; supervision, D.D. and A.C. All authors have read and agreed to the published version of the manuscript.

Funding: This research received no external funding.

Institutional Review Board Statement: Not applicable.

Informed Consent Statement: Not applicable.

Data Availability Statement: No new data were created or analyzed in this study. Data sharing is not applicable to this article.

Acknowledgments: This research effort was conducted under the MARPART-2 MAN and MAREC/ SAMRISK Projects. The views herein are solely of the authors and do not represent the views of the Department of Homeland Security/U.S. Coast Guard, or any other organization with a similar scope.

Conflicts of Interest: The authors declare no conflict of interest.

\section{Appendix A}

Table A1. Summary table of U.S. Arctic coastal ports. ${ }^{1,2}$

\begin{tabular}{ccc}
\hline Port Name & Port Characteristics & Environmental Risks/Concerns \\
\hline Kaktovik & $\begin{array}{c}\text { Beach landing; marine header; } \\
\text { tank farm }\end{array}$ & $\begin{array}{c}\text { Increased polar bear presence; permafrost thaw; potential oil and } \\
\text { gas development; receding sea-ice }\end{array}$ \\
\hline Prudhoe Bay & Beach landing; oil rig & Pollution (oil spills) \\
\hline Utqiagvik & $\begin{array}{c}\text { Beach landing; breakwater; } \\
\text { coastal protection measures; } \\
\text { small dock and boat launch; } \\
\text { tank farm }\end{array}$ & $\begin{array}{c}\text { Change in bowhead migration route; coastal erosion; drinking } \\
\text { water contamination; flooding; receding sea-ice }\end{array}$ \\
\hline
\end{tabular}


Table A1. Cont.

\begin{tabular}{ccc}
\hline Port Name & Port Characteristics & Environmental Risks/Concerns \\
Wainwright & $\begin{array}{c}\text { Beach landing; } \\
\text { coastal protection measure; } \\
\text { marine header }\end{array}$ & $\begin{array}{c}\text { Coastal erosion threatening historic sites; } \\
\text { flooding; potential oil and gas development; permafrost thaw; } \\
\text { riverine erosion }\end{array}$ \\
\hline Point Lay & $\begin{array}{c}\text { Beach landing } \\
\text { (with gravel road) }\end{array}$ & $\begin{array}{c}\text { Receding sea-ice; coastal erosion; walrus depletion; change in } \\
\text { caribou migration route }\end{array}$ \\
\hline Point Hope & Beach landing & Coastal erosion; flooding \\
\hline Red Dog & $\begin{array}{c}\text { Beach landing; } \\
\text { mooring points }\end{array}$ & Pollution (lead, zinc) \\
\hline
\end{tabular}

\footnotetext{
${ }^{1}$ Created by the authors with data adapted from [49]. ${ }^{2}$ Ports listed here also appear as port cities with connecting conceptual routes for the U.S. Coast Guard Alaskan Arctic Coast Port Access Route Study (AACPARS Brochure) [50].
}

Table A2. Summary table of Canadian Arctic coastal ports. ${ }^{1,2}$

\begin{tabular}{|c|c|c|}
\hline Port Name & Port Characteristics & Environmental Risks/Concerns \\
\hline Pond Inlet & $\begin{array}{l}\text { Marine dock; } \\
\text { mooring bollards }\end{array}$ & $\begin{array}{l}\text { Shoreline erosion; behavioral changes in wildlife; pollution } \\
\text { (oil spill) }\end{array}$ \\
\hline Resolute Bay & Beach landing & $\begin{array}{l}\text { Ships anchor locations disturbing marine mammals; noise pollution } \\
\text { impacting marine mammal migration routes; invasive species } \\
\text { pollution (oil pill) }\end{array}$ \\
\hline Tuktoyaktuk & $\begin{array}{l}\text { Marine resupply } \\
\text { facility }\end{array}$ & $\begin{array}{l}\text { Invasive species; behavioral changes in wildlife (whales, polar } \\
\text { bears, caribou, muskox, and birds); icebreaking impact to polar } \\
\text { bear food chain; pollution (oil spill) }\end{array}$ \\
\hline $\begin{array}{l}\text { Sachs } \\
\text { Harbour }\end{array}$ & $\begin{array}{l}\text { Marine resupply } \\
\text { facility }\end{array}$ & $\begin{array}{l}\text { Invasive species; behavioral changes in wildlife (whales, polar } \\
\text { bears, and fish); increased number of whale strikes; pollution } \\
\text { (oil spill); } \\
\text { icebreaking impact to caribou migration; } \\
\text { changing sea ice conditions resulting in higher sea state and wave } \\
\text { action erosion }\end{array}$ \\
\hline Ulukhaktok & $\begin{array}{l}\text { Marine resupply } \\
\text { facility }\end{array}$ & $\begin{array}{c}\text { icebreaking noise pollution disturbing polar bears; behavioral } \\
\text { changes in wildlife; destruction of animal habitat; impact to caribou } \\
\text { migration; pollution (oil spill) }\end{array}$ \\
\hline Paulatuk & $\begin{array}{l}\text { Marine resupply } \\
\text { facility }\end{array}$ & $\begin{array}{l}\text { Pollution; behavioral changes in wildlife; } \\
\text { icebreakers disruptive to polar bears and seals }\end{array}$ \\
\hline Gjoa Haven & $\begin{array}{l}\text { Marine dock; public dock; } \\
\text { floating dock; community crane; } \\
\text { tank farm }\end{array}$ & $\begin{array}{c}\text { Behavioral changes in wildlife; destruction of animal habitat; } \\
\text { pollution (oil spill); ship noise and traffic impacting wildlife } \\
\text { habitats and migratory routes }\end{array}$ \\
\hline Cambridge Bay & $\begin{array}{l}\text { Fixed dock; public/community } \\
\text { dock; floating dock; community } \\
\text { crane; tank farm }\end{array}$ & $\begin{array}{l}\text { Behavioral changes in wildlife; destruction of animal habitat; } \\
\text { disruption to caribou migration; pollution (oil spill) }\end{array}$ \\
\hline
\end{tabular}

${ }^{1}$ Created by the authors with various sources of data adapted from [51-66]. ${ }^{2}$ Ports listed are selected from two principal routes of the Northwest Passage that run along Baffin Bay, Lancaster Sound, Barrow Strait, Amundsen Gulf, Beaufort Sea, Victoria Strait.

\section{References}

1. NOAA. The Arctic Report Card 2020: The Sustained Transformation to a Warmer, Less Frozen and Biologically Changed Arctic Remains Clear. Available online: https:/ / arctic.noaa.gov / Portals /7 / ArcticReportCard/Documents / ArcticReportCard_full_ report2020.pdf (accessed on 3 February 2021).

2. PAME. The Increase in Arctic Shipping 2013-2019. Arctic Shipping Status Report (ASSR) \#1. Available online: https: // www.pame.is/document-library/shipping-documents / arctic-ship-traffic-data-documents/reports/752-arctic-shippingreport-1-the-increase-in-arctic-shipping-2013-2019-pdf-version-1/ file (accessed on 31 March 2020).

3. U.S. Committee on the Marine Transportation System. A Ten-Year Projection of Maritime Activity in the U.S. Arctic Region, 2020-2030; U.S. Committee on the Marine Transportation System: Washington, DC, USA, 2019. Available online: https: //www.cmts.gov/downloads/CMTS_2019_Arctic_Vessel_Projection_Report.pdf (accessed on 3 February 2021). 
4. Dalaklis, D.; Baxevani, E. Arctic in the Global Warming Phenomenon Era: New Maritime Routes \& Geopolitical Tensions. In New Maritime Routes: Origins, Evolution and Prospects; Delfour-Samama, D., Leboeuf, C., De Gwenaele, P.-M., Eds.; A. Pedone: Paris, France, 2016; ISBN 978-2-233-00792-6.

5. Dalaklis, D.; Drewniak, M. Search and Rescue Capabilities in the Arctic: Is the High North Prepared at an Adequate Level? In Crisis and Emergency Management in the Arctic Navigating Complex Environments; Andreassen, N., Borch, O.J., Eds.; Routledge: London, UK, 2020; Chapter 4.

6. Rodrigue, J. Transportation and Geography. In The Geography of Transport Systems, 5th ed.; Routeledge: New York, NY, USA, 2020; Chapter 1; ISBN 978-0-367-36463-2. Available online: https:/ / transportgeography.org/contents/chapter1/transportation-andspace/polar-shipping-routes / (accessed on 18 March 2021).

7. Dalaklis, D.; Baxevani, E. Maritime Transport in the Arctic After the Introduction of the Polar Code: A Discussion of the New Training Needs. In Sustainable Shipping in a Changing Arctic; Hildebrand, L., Brigham, L., Johansson, T., Eds.; WMU Studies in Maritime Affairs; Springer: Cham, Switzerland, 2018; Volume 7, pp. 383-398.

8. Drewniak, M.; Dalaklis, D. Ocean Governance Perspectives: The Case of the Arctic. Proc. Mar. Saf. Secur. Counc. 2019, 76, 13-18. Available online: https: / / pubs.royle.com/publication/?m=58884\&i=619807\&p=14 (accessed on 18 March 2021).

9. Lalonde, S. The U.S.-Canada Northwest Passage Disagreement: Why Agreeing to Disagree Is More Important Than Ever. In The Arctic and World Order; Spohr, K., Hamilton, D., Moyer, J., Eds.; Brookings Institute Press: Washington, DC, USA, 2020; Chapter 11; ISBN 978-0-9997406-8-2. Available online: https:/ / books.google.se/books?hl=en\&lr=\&id=eK8SEAAAQBAJ\&oi=fnd\&pg= PR7\&dq=the+arctic+and+the+world+order\&ots=j41o5d9-sM\&sig=HVQ29uHbXMdEaxI0-mFxApCEKsY\&redir_esc=y\#v= onepage\&q=the \%20arctic\%20and\%20the\%20world\%20order\&f=false (accessed on 18 March 2021).

10. Trudeau, J. U.S.-Canada Joint Statement on Climate, Energy, and Arctic Leadership. Prime Minister of Canada, News Release, 10 March 2016. Available online: https:/ / pm.gc.ca/en/news/statements/2016/03/10/us-canada-joint-statement-climate-energyand-arctic-leadership(accessed on 18 March 2021).

11. Nordregio. Sea Routes and Ports in the Arctic. January 2019. Available online: https://nordregio.org/wp-content/uploads/2019 /01/10330_Arctic_Sea_Transport.jpg (accessed on 18 March 2021).

12. Transport Canada. Government of Canada is Making Arctic Re-Supply Operations Safer and More Efficient for Remote Northern Communities, Through the Oceans Protection Plan. News Release. 26 April 2018. Available online: https: / / www.canada.ca/en/transport-canada/news/2018/04/government-of-canada-is-making-arctic-re-supply-operationssafer-and-more-efficient-for-remote-northern-communities-through-the-oceans-protection-plan.html (accessed on 18 March 2021).

13. Government of Northwest Territories. GNWT completes marine resupply for northern communities. In News Release; 30 September 2020. Available online: https:/ / www.gov.nt.ca/en/newsroom/gnwt-completes-marine-resupply-northern-communities (accessed on 3 February 2021).

14. Tower Arctic Ltd. Pond Inlet. Available online: https://www.towerarctic.net/pondinlet-en (accessed on 17 February 2021).

15. Baffinland Iron Mines Corporation Update to Credit Analysis. NunatsiaqNews. 30 June 2020. Available online: https://www. scribd.com/document/479477728/Moodys-Credit-Report-Update-on-Baffinland-June-2020 (accessed on 18 March 2021).

16. Baffinland. Expansion Project. Available online: https://www.baffinland.com/expansion-project/ (accessed on 15 February 2021).

17. Baffinland. Shipping \& Monitoring. Available online: https://www.baffinland.com/operation/shipping-and-monitoring/ (accessed on 15 February 2021).

18. Humpert, M. Shipping Traffic in Canadian Arctic Nearly Triples. High North News. 2 November 2018. Available online: https:/ / www.highnorthnews.com/en/shipping-traffic-canadian-arctic-nearly-triples (accessed on 1 February 2021).

19. Silber, G.; Adams, J. Vessel Operations in the Arctic. Front. Mar. Sci. 2019, 6, 573. [CrossRef]

20. Headland, R.K. Transits of the Northwest Passage to end of the 2019 Navigation Season-Atlantic Ocean-Arctic Ocean-Pacific Ocean; Scott Polar Research Institute, University of Cambridge: Cambridge, UK, 2020; Available online: https://www.spri.cam.ac.uk/ resources/infosheets/northwestpassage.pdf (accessed on 18 March 2021).

21. Drewniak, M.; Dalaklis, D.; Christodoulou, A.; Sheehan, R. Ice-Breaking Fleets of the United States and Canada: Assessing the Current State of Affairs and Future Plans. Sustainability 2021, 13, 703. [CrossRef]

22. Nordregio. Zones of Marine Activity in the Arctic. 28 July 2011. Available online: http://52.166.51.138:8080/en/Maps/05 -Environment-and-energy/Zones-of-marine-activity-in-the-Arctic/ (accessed on 18 March 2021).

23. U.S. Coast Guard. Arctic Strategic Outlook. Washington, D.C. April 2019. Available online: https://www.uscg.mil/Portals/0/ Images/arctic/Arctic_Strategy_Book_APR_2019.pdf (accessed on 3 February 2021).

24. Arctic Council. Arctic Marine Shipping Assessment 2009 Report, 2nd ed.; Arctic Council: Ottawa, ON, CA, 2009; Available online: https:/ / pame.is/images/03_Projects / AMSA/AMSA_2009_report/AMSA_2009_Report_2nd_print.pdf (accessed on 18 March 2021).

25. The International Council on Clean Transportation (ICCT). A 10-Year Projection of Maritime Activity in the U.S. Arctic Region; U.S. Committee on the Marine Transportation System. 2015. Available online: https://irma.nps.gov/DataStore/DownloadFile/552557 (accessed on 3 February 2021). 
26. U.S. Coast Guard. Port Access Route Study: In the Bering Strait. In Federal Register; 8 November 2010. Available online: https: / / www.federalregister.gov/documents/2010/11/08/2010-28115/port-access-route-study-in-the-bering-strait\#p-3 (accessed on 18 March 2021).

27. International Maritime Organization. Brief History of IMO. Available online: https://www.imo.org/en/About/HistoryOfIMO/ Pages/Default.aspx (accessed on 3 February 2021).

28. Silber, G.K. The role of the International Maritime Organization in Reducing Vessel Threat to Whales: Process, Options, Action, and Effectiveness. Mar. Policy 2012, 36, 1221-1233. Available online: https:/ / www.sciencedirect.com/science/article/pii/S030 8597X12000528?casa_token=q0bO1nqJdf0AAAAA:2_IJNyUQ_NPagLoCFdiLUMtxG9fO-79hx_ryZlM3HYoCIDzxIzdhiM2u2 7AoTnCXuIOfONxkKg\#bib21 (accessed on 18 March 2021). [CrossRef]

29. International Maritime Organization. Ships' Routeing. Available online: https://www.imo.org/en/OurWork/Safety/Pages/ ShipsRouteing.aspx\#: \{\}:text=As\%20well\%20as\%20traffic\%20separation, precautionary \%20areas \%20(where \%20ships\%20must (accessed on 3 February 2021).

30. International Maritime Organization. Procedure for the Submission of Documents Containing Proposals for the Establishment of, or Amendments to, Ships' Routeing Systems or Ship Reporting Systems, MSC.1/Circ. 1608. 20 August 2019. Available online: https://wwwcdn.imo.org/localresources/en/OurWork/Safety/Documents/Ships \T1 \textquoteright\%20routeing/MSC.1Circ.1608\%20-\%20Procedure\%20For\%20The\%20Submission\%20Of\%20Documents\%20Containing\%20Proposals\%20For\%20 The\%20Establishment\%20Of,\%20O.pdf (accessed on 18 March 2021).

31. U.S. Coast Guard. Marine Planning to Operate and Maintain the Marine Transportation System (MTS) and Implement National Policy. Commandant Instruction 16003.2B. 28 June 2019. Available online: https:/ / media.defense.gov/2019/Jul/10/2002155400/ -1/-1/0/CI_16003_2B.PDF (accessed on 18 March 2021).

32. U.S. Committee on the Marine Transportation System. Revisiting Near-Term Recommendations to Prioritize Infrastructure Needs in the U.S. Arctic; U.S. Committee on the Marine Transportation System: Washington, DC, USA, 2018. Available online: https:/ / www.cmts.gov/downloads/NearTermRecommendationsArctic2018.pdf (accessed on 3 February 2021).

33. Humpert, J. IMO Approves New shipping Corridors in Bering Sea to Improve Safety. High North News, 28 May 2018. Available online: https://www.highnorthnews.com/en/imo-approves-new-shipping-corridors-bering-sea-improve-safety(accessed on 3 February 2021).

34. U.S. Coast Guard. Arctic PARS. Available online: https://www.arcticpars.org/arcticpars (accessed on 3 February 2021).

35. U.S. Coast Guard. Port Access Route Study: Alaskan Arctic Coast. In Federal Register; 21 December 2018. Available online: https:/ / www.federalregister.gov/documents/2018/12/21/2018-27604/port-access-route-study-alaskan-arctic- (accessed on 18 March 2021).

36. Dawson, J. Infusing Inuit and Local Knowledge Into the Low Impact Shipping Corridors: An Adaptation to Increased Shipping Activity and Climate Change in Arctic Canada. Sci. Direct Environ. Sci. Policy 2020, 105, 19-36. Available online: https: / / www.sciencedirect.com/science/article/pii/S1462901119309451?via\%3Dihub (accessed on 18 March 2021). [CrossRef]

37. Arctic Corridors Research. Arctic Corridors Research for Policy on Shipping Governance in Arctic Canada. Available online: https: / / www.arcticcorridors.ca/ (accessed on 3 February 2021).

38. Beveridge, L. Arctic Pilots for Canadian Corridors: Is There a Role for Pilotage in the Canadian Low Impact Shipping Corridors? In The Ocean. Yearbook 32; Chircop, A., Coffen-Smout, S., McConnell, M., Eds.; Brill Nijhoff Publishers: Lieden, The Netherlands, 2018; Part 5; ISBN 978-90-04-36700-5.

39. Bloom, E.T. Establishment of the Arctic Council. Am. J. Int. Law 1999, 93, 712-722. [CrossRef]

40. Drewniak, M.; Dalaklis, D. Expansion of Business Activities in the Arctic: The Issue of Search and Rescue Services. In The Ocean. Yearbook 32; Chircop, A., Coffen-Smout, S., McConnell, M., Eds.; Brill Nijhoff Publishers: Lieden, The Netherlands, 2018; Part 5; ISBN 978-90-04-36700-5.

41. U.S. Department of State. Arctic Region, Office of Ocean and Polar Affairs. Available online: https://www.state.gov/key-topicsoffice-of-ocean-and-polar-affairs/arctic/ (accessed on 1 February 2021).

42. Arctic Council. Agreement on Cooperation on Aeronautical and Maritime Search and Rescue in the Arctic. 12 May 2011. Available online: https:/ / oaarchive.arctic-council.org/bitstream/handle/11374/531/EDOCS-3661-v1-ACMMDK07_Nuuk_2011_SAR_ Search_and_Rescue_Agreement_signed_EN_FR_RU.PDF?sequence=5\&isAllowed=y (accessed on 18 March 2021).

43. Arctic Council. Rovaniemi Ministerial Statements; Arctic Council Secretariat: Rovaniemi, Finland, 2019; ISBN 978-82-93600-50-3. Available online: https:/ / oaarchive.arctic-council.org/bitstream/handle/11374/2418/Rovaniemi_Ministerial_Statements.pdf? sequence $=1 \&$ isAllowed $=y$ (accessed on 22 March 2021).

44. Arctic Council. Fairbanks Declaration 2017, Fairbanks, AK, USA. 11 May 2017. Available online: https://oaarchive.arcticcouncil.org/bitstream/handle/11374/1910/EDOCS-4072-v5-ACMMUS10_FAIRBANKS_2017_Fairbanks_Declaration-2017 .pdf? sequence $=9 \&$ \&isAllowed $=y$ (accessed on 18 March 2021).

45. U.S. Department of Homeland Security. Arctic Search and Rescue Fiscal Year 2017 Report to Congress, Prepared by The U.S. Coast Guard. 13 March 2018. Available online: https:/ / www.dhs.gov/sites/default/files/publications/USCG\%20-\%20Arctic\% 20Search\%20and\%20Rescue_1.pdf (accessed on 18 March 2021).

46. U.S. Coast Guard. Coast Guard Concludes Operation Arctic Shield 2020. In News Release; 1 November 2020. Available online: https:/ / content.govdelivery.com/accounts/USDHSCG/bulletins/2a9276c (accessed on 18 March 2021). 
47. Canadian Coast Guard. Canadian Coast Guard Finishes Unique 2020 Arctic Operations Season. News Release. 11 December 2020. Available online: https://www.newswire.ca/news-releases/canadian-coast-guard-finishes-unique-2020-arctic-operationsseason-879008422.html (accessed on 18 March 2021).

48. Osthagen, A. The Arctic Coast Guard Forum: Big Tasks, Small Solutions. In Maritime Security Challenges: Focus High North. Papers from the Kiel Conference 2016; Bruns, S., Neumann, A., Eds.; Institute for Security Policy, Kiel University: Kiel, Germany, 2017; Available online: https:/ / www.ispk.uni-kiel.de/de/abteilung-maritime-strategie-und-sicherheit/publikationen/download/ kico-2016-proceedings (accessed on 22 March 2021).

49. Egge, N.; Feurer, A.; Jimenez, R.; Neumann, H.; Shyamakrishnan, K.; Stamson, N. Alaskan Arctic Coast Economic and Environmental Characterizations and Port Narratives. U.S. Coast Guard Office Standards Evaluation and Analysis Division. July 2020. Available online: https:/ / www.dco.uscg.mil/Portals/9/CG-5R/REG/AAC\%20Economic\%20and\%20Environmental\% 20Characterizations\%20and\%20Port\%20Narratives.pdf?ver=2020-07-16-020052-427 (accessed on 18 March 2021).

50. U.S. Coast Guard. Alaskan Arctic Coast Port Access Route Study (AACPARS). Available online: https://static1.squarespace. com/static/5d8930043ec7066969f72d77/t/5e3095badadfc12769801d45/1580242370914/AACPARS+Flyer.pdf (accessed on 4 February 2021).

51. Aarluk Consulting Inc. Infrastructure for a Sustainable Pond Inlet, Vol. 1 Community Priorities. 10 February 2011. Available online: http: / / toolkit.buildingnunavut.com/ICSP / Pond\%20Inlet/Pond\%20Inlet\%20ICISP\%20Volume\%201\%20Final\%20(2011 -03-04).pdf (accessed on 18 March 2021).

52. Arctic Corridors and Northern Voices Pond Inlet Nunavut 2018. Available online: https://www.arcticcorridors.ca/?acr_ download=\%2Fwp-content\%2Fuploads\%2F2019\%2F12\%2FUofO_CommReport_Pond-Inlet_2_FINAL_LO-2.pdf\&v=16122701 31629 (accessed on 18 March 2021).

53. Aarluk Consulting Inc. Infrastructure for a Sustainable Resolute Bay, Vol. 2 Report. 10 February 2011. Available online: http: / / toolkit.buildingnunavut.com/ICSP/Resolute\%20Bay /Resolute\%20Bay\%20ICISP\%20Volume\%202\%20Final\%20 (2011-04-05).pdf (accessed on 18 March 2021).

54. Arctic Corridors and Northern Voices Resolute Bay Nunavut 2019. Available online: https://www.arcticcorridors.ca/?acr_ download=\%2Fwp-content\%2Fuploads\%2F2019\%2F12\%2FUofO_CommReport_ResoluteBay_3_FINAL_LO-2.pdf\&v=161227 0131629 (accessed on 18 March 2021).

55. NWT Bureau of Statistics. Tuktoyaktuk Infrastructure Profile. Infrastructure Profiles. 2013. Available online: https://www. statsnwt.ca/community-data/Infrastructure\%20PDF/Tuktoyaktuk_in.pdf (accessed on 18 March 2021).

56. Arctic Corridors and Northern Voices Tuktoyaktuk 2018. Available online: https://www.arcticcorridors.ca/?acr_download=\%2 Fwp-content\%2Fuploads\%2F2019\%2F12\%2FUofO_CommReport_Tuktoyaktuk_2_FINAL_LO-2.pdf\&v=1612270131629 (accessed on 18 March 2021).

57. NWT Bureau of Statistics. Sachs Harbour Infrastructure Profile. Infrastructure Profiles. 2013. Available online: https://www. statsnwt.ca/community-data/Infrastructure\%20PDF/Sachs\%20Harbour_In.pdf (accessed on 18 March 2021).

58. Arctic Corridors and Northern Voices, Sachs Harbour Northwest Territories 2018. Available online: https://www.arcticcorridors. ca/?acr_download=\%2Fwp-content\%2Fuploads\%2F2019\%2F12\%2FUofO_CommReport_SachsHarbour_2_FINAL_LO-2.pdf\& $\mathrm{v}=1612270131629$ (accessed on 18 March 2021).

59. NWT Bureau of Statistics. Ulukhaktok Infrastructure Profile. Infrastructure Profiles. 2013. Available online: https://www. statsnwt.ca/community-data/Infrastructure\%20PDF/Ulukhaktok_In.pdf (accessed on 18 March 2021).

60. Arctic Corridors and Northern Voices, Ulukhaktok Northwest Territories 2018. Available online: https://www.arcticcorridors.ca/ ?acr_download=\%2Fwp-content \%2Fuploads\%2F2019\%2F12\%2FUofO_CommReport_Ulukhaktok_2_FINAL_LO-2.pdf\&v=16 12270131629 (accessed on 18 March 2021).

61. NWT Bureau of Statistics. Paulatuk Infrastructure Profile. Infrastructure Profiles. 2013. Available online: https://www.statsnwt. ca/community-data/Infrastructure\%20PDF/Paulatuk_In.pdf (accessed on 18 March 2021).

62. Arctic Corridors and Northern Voices, Paulatuk Northwest Territories 2018. Available online: https://www.arcticcorridors.ca/ ?acr_download=\%2Fwp-content\%2Fuploads\%2F2019\%2F12\%2FUofO_CommReport_Paulatuk_2_FINAL_LO-2.pdf\&v=1612 270131629 (accessed on 18 March 2021).

63. Aarluk Consulting Inc. Infrastructure for a Sustainable Gjoa Haven, Vol. 1. Community Priorities. 22 February 2011. Available online: http:/ / toolkit.buildingnunavut.com/ICSP/Gjoa\%20Haven/Gjoa\%20Haven\%20ICISP\%20Volume\%201\%20Final\%20 (2011-04-05).pdf (accessed on 18 March 2021).

64. Arctic Corridors and Northern Voices, Gjoa Haven Nunavut 2017. Available online: https://www.arcticcorridors.ca/?acr_ download=\%2Fwp-content\%2Fuploads\%2F2019\%2F12\%2FUofO_CommReport_GjoaHaven_5_FINAL_LO-2.pdf\&v=16122701 31629 (accessed on 18 March 2021).

65. Aarluk Consulting Inc. Infrastructure for a Sustainable Cambridge Bay, Vol. 1 Community Priorities. 28 February 2011. Available online: http:/ / toolkit.buildingnunavut.com/ICSP/Cambridge\%20Bay /Cambridge $\% 20$ Bay $\% 20 I C I S P \% 20 V o l u m e \%$ 201\%20Final\%20(2011-05-18).pdf (accessed on 18 March 2021).

66. Arctic Corridors and Northern Voices, Cambridge Bay Nunavut 2018. Available online: https://www.arcticcorridors.ca/?acr_ download=\%2Fwp-content\%2Fuploads\%2F2019\%2F12\%2FUofO_CommReport_CambridgeBay_9c_FINAL_LO-2.pdf\&v=16 12270131629 (accessed on 18 March 2021). 